\title{
Morphometric identification of small mammal footprints from ink tracking tunnels in the Brazilian Cerrado
}

\author{
Alexandre R. T. Palma ${ }^{1}$ \& Rodrigo Gurgel-Gonçalves ${ }^{2}$ \\ ${ }^{1}$ Departamento de Ecologia, Instituto de Ciências Biológicas, Universidade de Brasília. 70910-900 Brasília, Distrito Federal, \\ Brasil. E-mail:artpalma@dse.ufpb.br \\ ${ }^{2}$ Corresponding author. Laboratório de Zoologia, Curso de Ciências Biológicas, Universidade Católica de Brasília. \\ QS 07 Lote 1 EPTC Bloco M, 72030-170 Águas Claras, Distrito Federal, Brasil. E-mail: rgurgel@ucb.br
}

\begin{abstract}
An alternative method for identifying and inventorying rodents and marsupials inhabiting forests and grasslands of Brazilian Cerrado is presented and discussed. Ink tracking tunnels were designed according to the size of target species and used to build a reference collection of small mammal footprints composed of 1408 footprints belonging to 251 individuals from 30 species ( 21 rodents and nine marsupials). Sherman traps and ink tracking tunnels were used to conduct inventories in gallery forests. Footprints obtained in ink tracking tunnels were digitalized and compared with those in reference collection using Discriminant Analysis (DFA). DFA allowed good footprint differentiation, even among congeneric species. In DFA analysis, the first two axis were related to size and arboreality. The efficiency of ink tracking tunnels was higher (track-success $=31 \%$ ) than conventional trapping (trap-success $=14 \%$ ) in inventories. Ink tracking tunnels gave a good description of the small mammal community of gallery forest by detecting rodents and marsupials of different habits, including trap-shy species. This paper also discusses advantages and limitations of ink tracking tunnels use in inventories and ecological studies, and concludes that this technique can be efficient in long-term studies and in rapid inventories as a complementary technique for trapping.
\end{abstract}

KEY WORDS. Discriminant analysis; marsupials; rodents; shape; size; tracks.

RESUMO. Identificação morfométrica de pequenos mamíferos usando tubos de pegadas no Cerrado. Um método alternativo de identificação e inventário de roedores e marsupiais de florestas e áreas abertas do Cerrado é apresentado e discutido. Os tubos de pegadas foram projetados de acordo com o tamanho das espécies alvo e usados para construir uma coleção de referência de pegadas de pequenos mamíferos formada por 1408 pegadas pertencentes a 251 indivíduos de 30 espécies (21 roedores e nove marsupiais). Armadilhas Sherman e tubos de pegadas foram usados para conduzir inventários em matas de galeria. As pegadas obtidas nos tubos foram digitalizadas e comparadas com as da coleção de referência usando Análise Discriminante (DFA). Essas análises produziram boa diferenciação de pegadas, mesmo entre espécies congenéricas. Na análise DFA, os dois eixos foram relacionados a tamanho e arborealidade. A eficiência dos tubos de pegadas foi maior (sucesso dos tubos de pegadas $=31 \%$ ) que a armadilhagem convencional (sucesso das armadilhas $=14 \%$ ) nos inventários. Os tubos de pegadas forneceram boa descrição da comunidade de pequenos mamíferos em matas de galeria, detectando roedores e marsupiais de diferentes hábitos, incluindo espécies que dificilmente são capturadas. Este trabalho também discute vantagens e limitações do uso dos tubos de pegadas em inventários e estudos ecológicos e conclui que esta técnica pode ser eficiente na realização de estudos de longo prazo e de inventários rápidos, como uma técnica complementar à armadilhagem.

PALAVRAS-CHAVE. Análise discriminante; marsupiais; roedores; forma; tamanho.

Clear and complete footprints of small mammals are rarely found in nature, unless in exceptional conditions (fine dust and mud). Accurate identification is a difficult task, because many species have similar tracks. Therefore, Neotropical rodents and marsupials are underrepresented in track guides
(Emmons \& Feer 1997, Reid 1997, Becker \& Dalponte 1999). Some methods were developed to detect small mammal footprints like shelters containing smoked paper (MAYER 1957, Justice 1961, Sheppe 1965, Johns 1979), smoked paper discs (MarTEN 1972), sooted aluminum plates (TAYLOR \& RAPHAEL 1988, CAREY 
$\&$ WITT 1991) plates coated with talcum powder solution (Brown 1969, Lieberman 1973, Boonstra et al. 1992) or chalk solution (DRENNAN et al. 1998), white tiles partially coated with a mixture of printing ink and mineral spirits (LoRD et al. 1970) and ink tracking tunnels (tunnels hereafter) (KING \& EDGARD 1977, Apeldoorn et al. 1993, Ratz 1997). This last method offers some advantages: providing footprints with good resolution and a permanent record that is easy to handle and stock for later analysis. Footprints obtained using this method could be examined for consistency of the overall shape, arrangement of toe and sole (plantar) pad prints and for the range of print sizes for each of the species (APELDoorn et al. 1993, RATZ 1997).

The Neotropical Didelphids, Echimyids and Sigmodontine Murids are speciose groups. The last two groups are particularly conservative in number and general arrangement of toe and sole pads. Despite their conservative foot morphology, these groups show a wide array of locomotion modes and an ample body size range (Fonseca et al. 1996), suggesting that reliable identifications could be obtained by using morphometric analysis. This included the use of a minimally redundant set of distances among toe and sole pads, the Truss method (Strauss \& Bookstein 1982), and multivariate analysis of these distances (Smallwood \& Fitzhugh 1993).

The aims of our study were 1) to adapt the tunnel design to sample small mammals in forests of central Brazil, 2) to create a reference collection of small mammals tracks for this same region and develop a method to identify them, 3) to use this method to identify tracks obtained in field inventories and compare its efficiency with traps in small mammal inventories.

\section{MATERIAL AND METHODS}

\section{Tunnel design}

We used a modified design of the device presented by APELDOoRn et al. (1993) to make the tunnels, incorporating adaptations regarding the step length and size of native small mammals, and transport viability. Tunnels of three different sizes were made by cutting PVC water pipe tubes (Tab. I). The inner surface of PVC tubes were covered by form feed printing paper (two-three connected sheets), the ink reservoir was created with a plastic tube cut from middle portion of a two liter plastic soft drink bottle. The plastic tube fits nicely inside the large PVC tubes (diameter: $10 \mathrm{~cm}$ ), and it can be cut along its length and rolled up to fit into medium and small tubes (diameters: $7.5 \mathrm{~cm}$, and $5 \mathrm{~cm}$, respectively). The ink reservoir was placed inside the central part of PVC. In field situations this allows recording of animals entering from both sides (Fig. 1). We used blue ink stamp (PILOT). Previous tests showed that this ink provided footprints with good resolution for at least 16 days in laboratory conditions and seven days in field conditions (during dry season).

The bait was placed out of reach of the animals, in a space between the outer ink reservoir and the inner PVC tube surfaces (Fig. 1). To open this space, we inserted a stick be- tween the plastic ink reservoir and the PVC pipe. In this way a baited tunnel could attract multiple specimens.

Working in the field, we observed that recharging the ink and bait in the small and medium sized tunnels was a difficult task because we could not reach the center of the tunnels by hand. To solve this problem we cut transversely these tunnels in two halves, and at the end of one of the halves we molded a flange by heating it in boiling water to create a slip to rejoin both halves. In this way we could separate the halves to recharge the ink and bait, and reconnect them again.

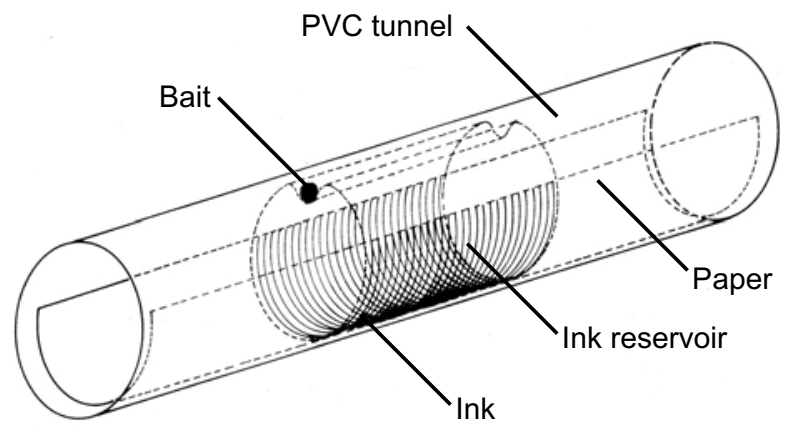

Figure 1. Components of an ink tracking tunnel.

\section{Track collection and identification}

Small mammal tracks were collected in two situations: tracks produced by trapped and identified individuals (reference tracks) and tracks of unknown free-ranging individuals (field tracks).

We built a reference collection of small mammal tracks using animals captured during a study on community structure in different habitats of the Brazilian Cerrado, mainly in gallery forests, but also in savannas, grasslands and swamps. The animals captured during a three-year period (2000-2002) were identified (species, sex, age, and collector number) and encouraged to walk through the tunnel at least three times or until we obtained footprints of good quality. In order to acquire longer track trails as reference material we placed the ink reservoir at one extremity of an unbaited tunnel.

The best footprints (three anterior footprints and three posterior footprints, including right and left ones) obtained from each identified individual were selected. These footprints were scanned in $400 \mathrm{dpi}$ resolution, reoriented (left ones were flipped to become comparable to right ones), and digitalized using Carta Linx software. Coordinates of each footprint (centers of toe and sole pad prints) were used to calculate distances between pads. We then selected a set of pad distances using the Truss method (Strauss \& Bookstein 1982) along with some adaptations: the truss was constructed initially with central sole pads (rigid part of feet) and then with toe pads (mobile part), connecting adjacent toes and toes to central pads (Fig. 2). Dis- 
Table I. Tracking tunnel sizes used for small mammals found in Brazilian Cerrado. We used the following guidelines for size adjustment: minimum length of ink reservoir (two steps), minimum length of paper on each side of ink reservoir (three steps), maximum total length suitable for transport and handling $(90 \mathrm{~cm})$. Medium and small tubes are mounted using two sections of PVC tubes.

\begin{tabular}{|c|c|c|c|}
\hline & Large & Medium & Small \\
\hline Target species & Didelphis albiventris & Proechimys longicaudatus & Oryzomys megacephalus \\
\hline Mean Weight (g) & 1250 & 250 & 60 \\
\hline Maximum step length (cm) & 10.0 & 6.5 & 5.0 \\
\hline \multicolumn{4}{|c|}{ Measurements of tracking tunnel } \\
\hline Paper length $(\mathrm{cm})$ & $37 \times 2$ & $22 \times 2$ & $22 \times 2$ \\
\hline Ink reservoir length $(\mathrm{cm})$ & 16 & 16 & 16 \\
\hline Total PVC tube length $(\mathrm{cm})$ & 90 & $31 \times 2$ & $31 \times 2$ \\
\hline Tube diameter $(\mathrm{cm})$ & 10.0 & 7.5 & 5.0 \\
\hline
\end{tabular}
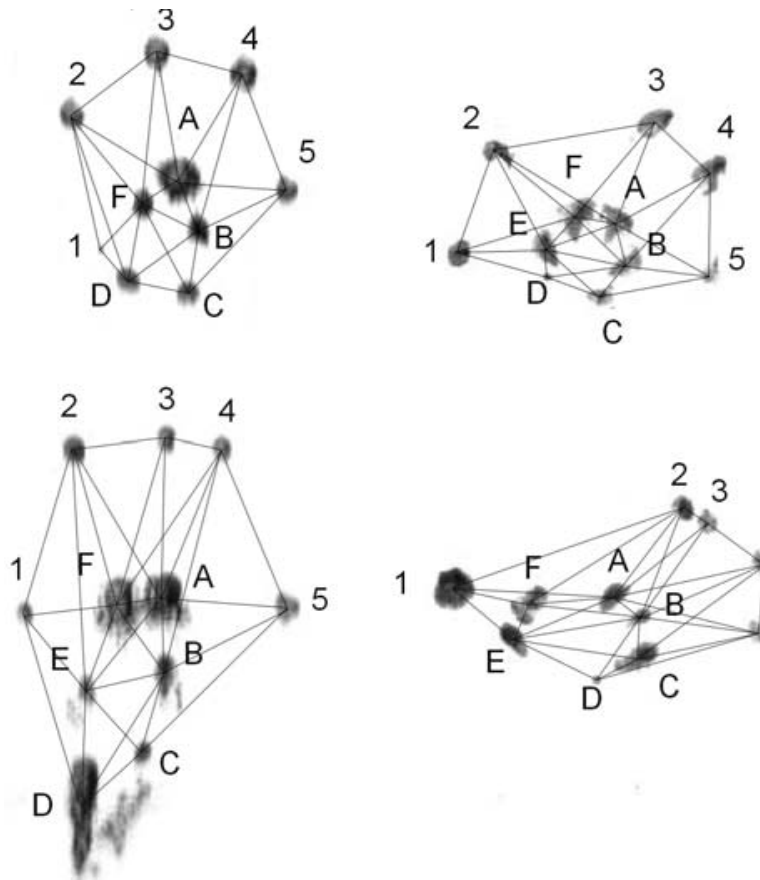

Figure 2. Right footprints of rodents (left) and marsupials (right). Anterior footprints (above) and posterior ones (below). Toe pads are identified by numbers and central pads by letters (after APELDOORN et al. 1993). Lines connecting pads represent distances used in multivariate analysis.

tances were transformed $\left(\mathrm{x}^{\prime}=\log [\mathrm{x}]\right)$, standardized $($ mean $=0$ and variance $=1$ ) and used to differentiate species represented in reference collection using Discriminant Analysis (DFA).

Sampling tracks of free-ranging individuals poses a problem. Different free-ranging individuals of the same or different species can enter a given tunnel. Since we were not able to differentiate tracks of conspecific individuals, we defined all footprints of a given species in one tunnel as a single record, not considering if they were left by different individuals or during different nights. So field tracks of a record were processed right the same way as reference tracks of a single known individual. This resulted in each field record having (if possible) three forefeet replicates and three hindfeet replicates in data set.

Identification of field footprints was made by comparing them with reference footprints using DFA. Classification of field footprints in a given species was done in four steps. First, we checked if DFA generated a good model of discrimination among groups (species) by looking at the efficiency of Discriminant Functions in correctly classifying the reference footprints. We only accepted classification models that classified correctly more than $95 \%$ of reference footprints. Second, when this efficiency rate threshold was not reached, we reduced the number of groups (by eliminating clearly dissimilar species), in order to reduce the noise of dissimilar species in the data, and tested the discrimination among groups again. Third, if discrimination among groups remained poor, footprints were considered as unidentified. If discrimination among groups was good (>95\%), then each field footprint was assigned to its most probable group as indicated by Discriminant Functions. Fourth, identification of a given record was confirmed only if the following criteria were met: 1) if all the replicates (anterior and posterior ones) of that record were classified in the same group with $p>0.95$ and 2) if the all replicates of that record were found inside the same cloud of reference footprints (= a species in the reference collection) in the DFA graphs. This second criterium avoided wrong footprint identifications of rare species not included in our reference collection.

\section{Tunnels as inventory method}

We made two inventories using tunnels in a gallery forest along Taquara stream at RECOR (Reserva Ecologica do Instituto Brasileiro de Geografia e Estatística) near Brasília, Fed-

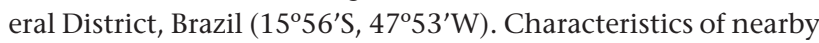
similar gallery forests were described by RATTER (1980), NitIKMAN \& Mares (1987), and Silva JúNIOR et al. (1998).

The first inventory (August 2000) was a preliminary one, and we used only tunnels. In the second inventory (August 2001) we combined traps and tunnels in order to compare the

Revista Brasileira de Zoologia 24 (2): 333-343, junho 2007 

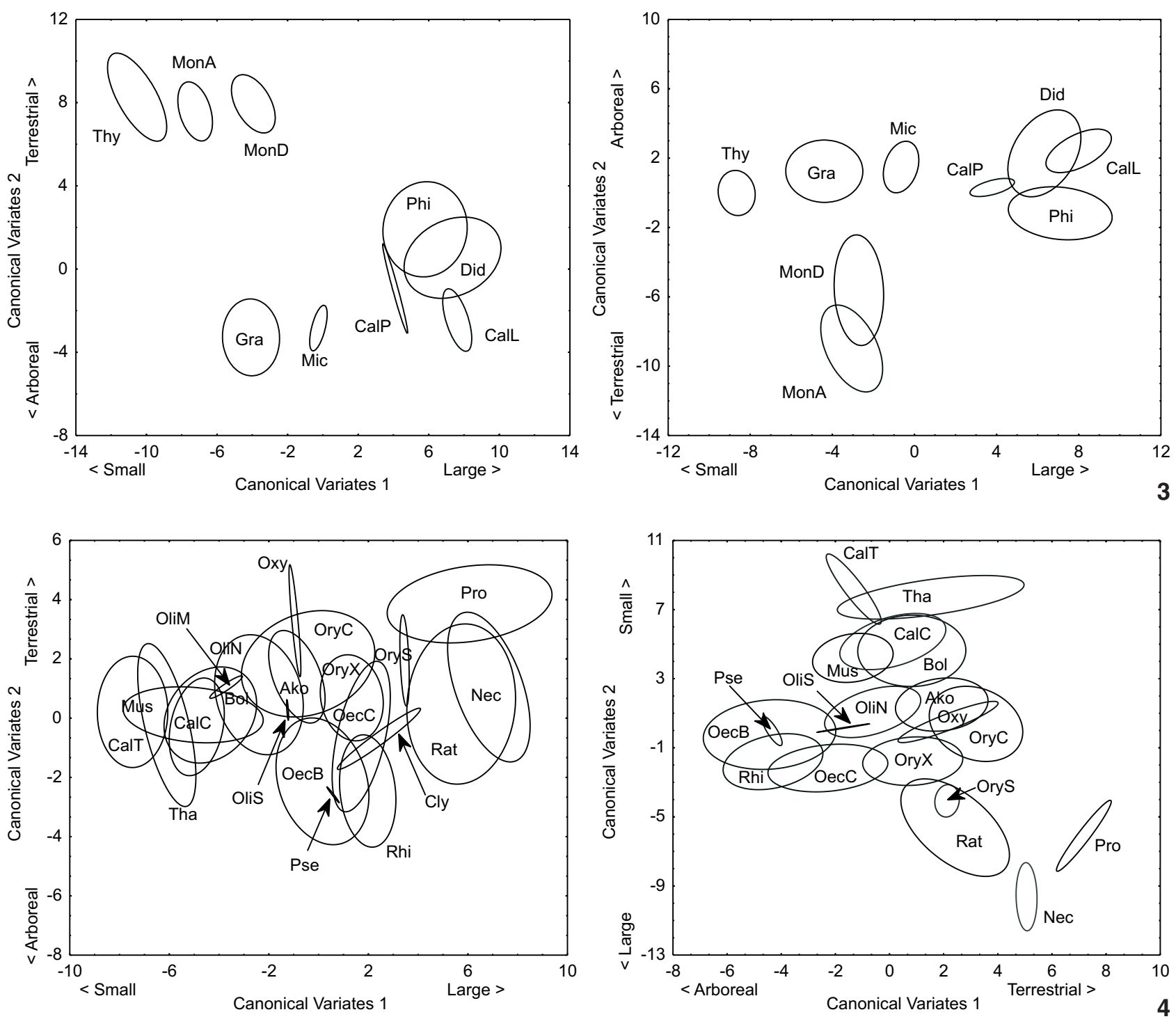

Figures 3-4. Discriminant analysis of: (3) marsupial footprints with $95 \%$ concentration ellipses of anterior (left: $\lambda=0.001, F=14.22$, d.f. $=200,1200, p<0.001$ ) and posterior footprints (right: $\lambda=0.001, F=16.19$, d.f. $=176,1176, p<0.001$ ); (4) rodent footprints with $95 \%$ concentration ellipses of anterior (left: $\lambda=0.001, F=13.88$, d.f. $=456,7465, p<0.001$ ) and posterior footprints (right: $\lambda=0.004$, $\mathrm{F}=12.25$, d.f. $=400,6579, \mathrm{p}<0.001)$. Species codes as in table II.

efficiency of both methods. In both inventories we used equal numbers of different sized tunnels, half set on the ground, half set on horizontal vines or tree branches ( 1 to $2 \mathrm{~m}$ high) using rubber strips. The bait was a mixture of banana, peanut cream, corn flour and sardines.

In August 2000 we used 36 tunnels (18 on the ground and 18 in the understory) arranged in a $6 \times 3$ grid (spacing = $7 \mathrm{~m}$ ). The tunnels were monitored after four and seven nights totaling a sampling effort of 252 tunnels-night.

In August 2001, we set two transects with 30 stations

Revista Brasileira de Zoologia 24 (2): 333-343, junho 2007
(290 m long, spacing $=10 \mathrm{~m})$ in Taquara gallery forest $100 \mathrm{~m}$ apart from each other. In one transect we put 60 Sherman traps and in the other 60 tunnels (30 pieces on the ground and 30 in the understory of each transect). We used the same bait for traps and tunnels. After four nights, the traps were replaced by tunnels and vice-versa, remaining in the transect for another four-night period, totaling a sampling effort of 240 tunnelsnight and 240 traps-night in each transect. Both transects were checked daily, but track records were collected only after the fourth night. 
Table II. Number of individuals and digitalized footprints in reference collection from animals captured in three-year period (2000-2002) in Brazilian Cerrado. Weight and locomotion mode after FonsECA et al. (1996), modified by information in: (A) in EMMONS \& FeER (1997).

\begin{tabular}{|c|c|c|c|c|c|c|}
\hline \multirow{2}{*}{ Species } & \multirow{2}{*}{ Code } & \multirow{2}{*}{$\begin{array}{l}\text { Number of } \\
\text { individuals }\end{array}$} & \multicolumn{2}{|c|}{ Number of footprints } & \multirow{2}{*}{ Weight (g) } & \multirow{2}{*}{$\begin{array}{l}\text { Locomotion } \\
\text { mode }\end{array}$} \\
\hline & & & Anterior & Posterior & & \\
\hline \multicolumn{7}{|l|}{ Marsupials } \\
\hline \multicolumn{7}{|l|}{ Didelphidae } \\
\hline Caluromys philander (Linnaeus, 1758) & CalP & 1 & 3 & 3 & 170 & Arboreal \\
\hline Caluromys lanatus (Olfers, 1818) & CalL & 2 & 6 & 6 & 356 & Arboreal \\
\hline Didelphis albiventris Lund, 1840 & Did & 9 & 26 & 24 & 1250 & Scansorial \\
\hline Gracilinanus agilis (Burmeister, 1854) & Gra & 34 & 90 & 89 & 30 & Scansorial \\
\hline Micoureus demerarae (Thomas, 1905) & Mic & 3 & 9 & 9 & 105 & Arboreal \\
\hline Monodelphis americana (Müller, 1776) & MonA & 3 & 9 & 9 & 29 & Terrestrial \\
\hline Monodelphis domestica (Wagner, 1842) & MonD & 3 & 9 & 6 & 67 & Terrestrial \\
\hline Philander opossum (Linnaeus, 1758) & Phi & 14 & 42 & 42 & 360 & Terrestrial \\
\hline Thylamys velutinus (Wagner, 1842) & Thy & 2 & 6 & 5 & 24 & Terrestrial \\
\hline \multicolumn{7}{|l|}{ Rodents } \\
\hline \multicolumn{7}{|l|}{ Muridae } \\
\hline \multicolumn{7}{|l|}{ Murinae } \\
\hline Mus musculus Linnaeus, 1758 & Mus & 7 & 22 & 21 & 16 & Scansorial ${ }^{A}$ \\
\hline Rattus norvegicus (Berkenhout, 1769) & Rat & 9 & 27 & 27 & 353 & Terrestrial ${ }^{\mathrm{A}}$ \\
\hline \multicolumn{7}{|l|}{ Sigmodontinae } \\
\hline Akodon cursor (Winge, 1887) & Ako & 11 & 33 & 30 & 38 & Terrestrial \\
\hline Necromys lasiurus (Lund, 1840) & Bol & 18 & 36 & 36 & 35 & Terrestrial \\
\hline Calomys tener (Winge, 1887) & CalT & 6 & 12 & 9 & 20 & Terrestrial \\
\hline Calomys callosus (Rengger, 1830) & CalC & 5 & 15 & 15 & 31 & Terrestrial \\
\hline Nectomys squamipes (Brants, 1827) & $\mathrm{Nec}$ & 5 & 15 & 12 & 249 & Semiaquatic \\
\hline Oecomys bicolor (Tomes, 1860) & OecB & 30 & 90 & 89 & 28 & Arboreal \\
\hline Oecomys concolor (Wagner, 1845) & OecC & 6 & 18 & 18 & 60 & Arboreal \\
\hline Oligoryzomys nigripes (Olfers, 1818) & OliN & 8 & 24 & 24 & 21 & Scansorial \\
\hline Oligoryzomys stramineus Bonvicino \& Weksler, 1998 & Olis & 1 & 3 & 3 & 29 & Scansorial? \\
\hline Oligoryzomys microtis (Allen, 1916) & OliM & 1 & 3 & 3 & 27 & Scansorial \\
\hline Oryzomys megacephalus (Fischer, 1814)* & OryC & 29 & 87 & 82 & 59 & Terrestrial \\
\hline Oryzomys subflavus (Wagner, 1842)* & Orys & 1 & 3 & 3 & 92 & Terrestrial \\
\hline Oryzomys scotti Langguth \& Bonvicino, 2002* & OryX & 12 & 36 & 36 & 92 & Terrestrial \\
\hline Oxymycterus delator Thomas, 1903 & Oxy & 1 & 3 & 3 & 83 & Terrestrial A \\
\hline Rhipidomys macrurus (Gervais, 1855) & Rhi & 21 & 66 & 66 & 80 & Arboreal \\
\hline Thalpomys cerradensis Hershkovitz 1990 & Tha & 2 & 4 & 4 & 24 & Terrestrial \\
\hline Pseudoryzomys sp. & Pse & 1 & 3 & 3 & 33 & Arboreal? \\
\hline \multicolumn{7}{|l|}{ Echimyidae } \\
\hline Clyomys laticeps (Thomas, 1909) & Cly & 1 & 3 & 2 & 170 & Fossorial \\
\hline Proechimys longicaudatus (Rengger, 1830) & Pro & 5 & 13 & 13 & 210 & Terrestrial \\
\hline Total & & 251 & 716 & 692 & & \\
\hline
\end{tabular}

* A very recent study (WEKSLER et al. 2006) divided the genus Oryzomys in ten genera. Following this study, the new valid names are Hylaeamys megacephalus, Cerradomys scotti and Cerradomys subflavus. 


\section{RESULTS}

\section{Tunnel design}

The tunnel design was useful in field situations, since we were able to obtain good footprints of free-ranging animals of different body sizes [from Gracilinanus agilis (Burmeister, 1854) $(\approx 25 \mathrm{~g}$ ) to Didelphis albiventris (Lund, 1840) $(\approx 1000 \mathrm{~g})]$, of different habits [Rhipidomys macrurus - arboreal, G. agilis scansorial, Monodelphis spp. - cursorial, Oxymycterus delator (Thomas, 1903) - semi-fossorial], in different vegetation strata (ground and understory), and during dry and rainy periods.

Baited tunnels were so attractive to free-ranging small mammals that we could get up to four records (of different species) in the same tunnel after a four-night period, as well as footprints of trap-shy species (Monodelphis spp.).

Sometimes free-ranging animals left an excess of footprints in the tunnel that prejudiced identification. The average number of footprints per tunnel left by free-ranging animals was $110 \pm 43(\mathrm{n}=7)$ for $G$. agilis, $16 \pm 8(\mathrm{n}=5)$ for $D$. albiventris/Philander opossum (Linnaeus, 1758), $25 \pm 14(\mathrm{n}=6)$ for Monodelphis sp. and $28 \pm 11(n=6)$ for rodents in general.

\section{Track collection and identification}

We built a reference collection composed of 1408 reference footprints obtained from 251 individuals of 30 species (21 rodents and 9 marsupials) captured in gallery forests and grasslands of the Brazilian Cerrado (Tab. II). Footprints of some genera (Monodelphis, Rattus, Proechimys and Nectomys) were so distinctive that they could be identified by direct comparison with the reference collection.

Analyzing field and reference footprints with DFA we were able to identify footprints of small mammals living in forests and grasslands. The discriminant models created by DFA had a high rate of correct classifications of the reference footprints, showing great differentiation among species. The percentage of correct classifications was higher among marsupials (93.8\% for anterior footprints and $97.3 \%$ for posterior ones) than rodents $(74.0 \%$ for anterior footprints and $88.3 \%$ for posterior ones). In both groups posterior footprints were better in differentiating species, showing a lesser degree of species overlap in DFA graphs (Figs 3 and 4, Tabs III and IV). The percentage of correct classifications in each group (genera) varied from 67 to $100 \%$ for rodents and from 88 to $100 \%$ for marsupials.

Inspection of DFA graphs showed that differences among species are related to body size and feet morphology, both related to locomotory behaviour. Discriminant Analyses of rodent and marsupial footprints (both anterior and posterior ones) showed a similar arrangement of species footprints: the first two Discriminant Functions represented a sequence from small to large species and a sequence from terrestrial through scansorial to arboreal species (Figs 3 and 4).

Discrimination among groups of footprints species was better when we used fewer species in DFA, resulting in higher percentage of correct classifications of reference footprints in groups as the noise due to dissimilar species was removed from analysis. Discriminant analysis of posterior footprints of congeneric species (see Tab. II for species list) showed an even higher percentage of correct classifications for Monodelphis spp. (100\%), Oecomys spp. (97.3\%), Calomys spp. (100\%), Oryzomys spp. (97.9\%, Fig. 5), and Oligoryzomys spp. (100\%).

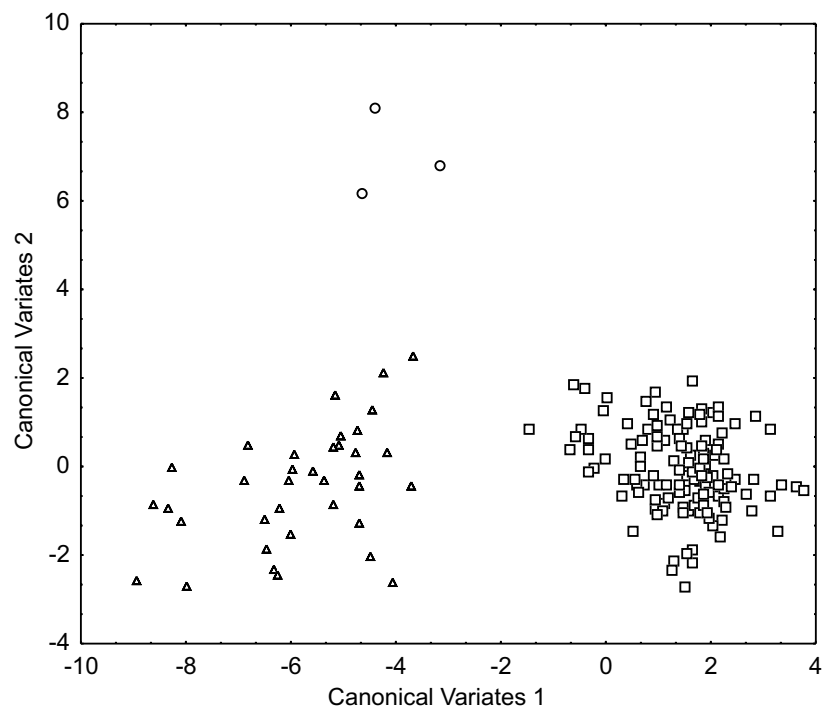

Figure 5. Discriminant Analysis of posterior footprints of three species of Oryzomys ( $\lambda=0.076, F=15.46$, d.f. $=56,328, p<0.001$ : 0 . subflavus (circle), O. scotti (triangle) and O. megacephalus (square).

\section{Tunnels as inventory method}

In the first inventory (August 2000), we obtained 65 track records (record of one species in a given tunnel) of at least seven species, resulting in a record success rate (track records/ tunnels-night) of 25.8\%. In the second inventory (August 2001) we obtained 149 track records and 68 captures of at least 8 species (Tab. V). In this inventory, the overall efficiency of the tunnel (31.0\%) was higher than the trapping by Sherman traps (14.1\%). The success of trapping and track-recording were lower in the first week ( $8.3 \%$ and $27.9 \%$, respectively), than in the second week $(20.0 \%$ and $34.1 \%$, respectively).

In the second inventory, the numbers of captures and track records of each species were not significantly correlated (Tab. V, Spearman correlation, $\mathrm{r}_{\mathrm{s}}=0.573, \mathrm{p}=0.137$ ), suggesting that species exhibited different responses to traps and tunnels. Considering the same sampling effort used in these two techniques, some species had similar responses to both techniques [Proechimys longicaudatus (Rengger, 1830), R. macrurus] while others had better responses to tunnels like Monodelphis spp. and Oryzomys megacephalus (Fischer, 1814) that were detected only by tunnels. No species were detected only by trapping. 
Morphometric identification of small mammal footprints from ink tracking tunnels...

Table III. Discriminant functions (DF) of DFA of measures of posterior footprints and anterior footprints of marsupials. Variable codes follow figure 2.

\begin{tabular}{|c|c|c|c|c|c|}
\hline \multicolumn{3}{|c|}{ Posterior footprints } & \multicolumn{3}{|c|}{ Anterior footprints } \\
\hline Variables & DF 1 & DF 2 & Variables & DF 1 & DF 2 \\
\hline$\overline{A B}$ & 0.13 & -0.50 & $\overline{A B}$ & 0.76 & 0.54 \\
\hline $\mathrm{AE}$ & 0.61 & -1.95 & $\mathrm{AF}$ & -0.21 & 1.92 \\
\hline $\mathrm{AF}$ & -0.94 & 2.61 & A2 & -0.73 & -1.38 \\
\hline $\mathrm{A} 1$ & 2.39 & -1.43 & A3 & 2.05 & -2.19 \\
\hline A2 & 0.63 & 0.03 & A4 & -1.28 & 3.23 \\
\hline $\mathrm{A} 3$ & 0.16 & -1.81 & A5 & -1.16 & .17 \\
\hline A4 & 0.05 & 1.40 & BC & 0.04 & 0.07 \\
\hline BC & 0.18 & -0.11 & $B D$ & 0.73 & -0.54 \\
\hline $\mathrm{BE}$ & 0.42 & 0.01 & $\mathrm{BF}$ & -0.69 & 0.23 \\
\hline $\mathrm{BF}$ & -0.50 & -0.14 & B4 & -0.95 & -0.09 \\
\hline B2 & -0.76 & -0.36 & B5 & 0.57 & -0.54 \\
\hline B3 & 0.24 & 0.97 & $C D$ & 0.22 & 0.31 \\
\hline B4 & -0.79 & -0.50 & C5 & 0.19 & 0.17 \\
\hline B5 & 0.52 & -1.01 & D1 & 1.09 & -0.68 \\
\hline $\mathrm{CE}$ & -0.32 & 1.21 & $\mathrm{~F} 1$ & -1.47 & 0.43 \\
\hline C4 & 0.90 & -0.30 & F2 & 0.15 & 1.93 \\
\hline C5 & -0.61 & 1.45 & F3 & -2.60 & 2.33 \\
\hline EF & 0.01 & 0.42 & $\mathrm{~F} 4$ & 3.01 & -3.99 \\
\hline $\mathrm{E} 1$ & 0.26 & -0.80 & 12 & 0.80 & -0.48 \\
\hline $\mathrm{F} 1$ & -1.29 & 1.64 & 23 & 1.20 & -1.96 \\
\hline $\mathrm{F} 2$ & 1.21 & -0.76 & 34 & -0.38 & 0.75 \\
\hline 12 & -1.86 & 1.54 & 45 & 0.16 & 0.27 \\
\hline 23 & 0.06 & 0.02 & & & \\
\hline 34 & 0.00 & -0.60 & & & \\
\hline 45 & 0.02 & 0.10 & & & \\
\hline Eigenvalue & 31.37 & 7.59 & & 33.37 & 15.11 \\
\hline Discriminating Information (\%) & 70 & 17 & & 62 & 29 \\
\hline
\end{tabular}

\section{DISCUSSION}

\section{Tunnel design}

Footprints obtained using the tunnels presented good resolution and were easy to stock and handle. The inventory method using tunnels was cheap (one tunnel costs US\$1.20), allowing flexibility in field situations, providing little interference in animal movements and protecting footprints from climatic factors. The check takes only about one minute per tunnel. The site is not disturbed and the footprints can be analyzed later. Using this method the presence of a field researcher is not necessary on a daily basis, like trapping. In addition, the method is harmless, not causing any stress situation to animals, while avoiding straight contact, as some small mammals species can be hosts of diseases like Hantaviruses and American Trypanosomiasis for example (Lenzi et al. 1984, Mills et al. 1995).
Two problems lead to data loss using tunnels: rainy weather and over-tracking. During the wet season, we observed that rain blurred $14 \%$ of track records (Tab. V). This was caused neither by flooding, nor by rain drops falling directly inside tunnels, but by droplets produced by rain drops splashing just outside the tube. Loss of data due to rain can be even more severe in grasslands than in forests. We solved this problem in further inventories in grasslands by protecting each open end of tunnel with a $90^{\circ}$ elbow PVC fitting slightly inclined downward.

Over-tracking caused by the high activity of mammals inside tunnels prejudiced footprint selection. The over-tracking problem was observed in other track studies (MARTEN 1972, KING \& EDGAR 1977) and could be minimized by changing the paper more frequently, by not baiting the tunnel in areas with high mammal activity, or by letting the animals remove the bait.

Revista Brasileira de Zoologia 24 (2): 333-343, junho 2007 
Table IV. Discriminant functions (DF) of DFA of measures of posterior footprints and anterior footprints of rodents. Variable codes follow figure 2 .

\begin{tabular}{|c|c|c|c|c|c|}
\hline \multicolumn{3}{|c|}{ Posterior footprints } & \multicolumn{3}{|c|}{ Anterior footprints } \\
\hline Variables & DF 1 & DF 2 & Variables & DF 1 & DF 2 \\
\hline$\overline{A B}$ & 0.95 & 0.51 & $A B$ & -0.19 & 0.12 \\
\hline $\mathrm{AE}$ & -0.65 & -0.13 & $\mathrm{AF}$ & -0.08 & -0.25 \\
\hline $\mathrm{AF}$ & 0.46 & 0.05 & A2 & 0.09 & 0.21 \\
\hline $\mathrm{A} 2$ & 1.92 & 0.56 & A3 & -0.11 & -0.28 \\
\hline A3 & -0.67 & -0.22 & A4 & -0.58 & -1.41 \\
\hline A4 & 0.20 & 0.39 & $B C$ & -0.13 & 0.12 \\
\hline A5 & 0.00 & 0.26 & $\mathrm{BD}$ & 0.25 & 0.01 \\
\hline BD & 0.16 & 0.17 & $\mathrm{BF}$ & -0.06 & -0.15 \\
\hline $\mathrm{BE}$ & -0.42 & -0.83 & B4 & 0.76 & 1.02 \\
\hline $\mathrm{BF}$ & -0.66 & -0.20 & B5 & -0.55 & 0.15 \\
\hline B4 & -0.42 & -0.72 & $C D$ & 0.32 & -0.23 \\
\hline B5 & -0.30 & -0.48 & CF & 0.05 & 0.00 \\
\hline $\mathrm{DE}$ & 0.03 & -0.22 & C5 & 0.62 & -0.51 \\
\hline D1 & -0.05 & 0.04 & DF & -0.18 & -0.75 \\
\hline $\mathrm{EF}$ & 0.85 & 0.23 & D2 & 0.32 & 2.09 \\
\hline E1 & -0.16 & -0.12 & F2 & -0.27 & -1.67 \\
\hline E2 & 0.64 & -0.24 & F3 & 0.24 & 0.60 \\
\hline F1 & -0.04 & 0.36 & 23 & 0.19 & 0.52 \\
\hline $\mathrm{F} 2$ & -2.15 & -0.42 & 34 & 0.37 & 0.23 \\
\hline $\mathrm{F} 3$ & 0.85 & 0.14 & 45 & 0.18 & -0.07 \\
\hline 12 & 0.39 & 0.12 & & & \\
\hline 23 & -0.23 & -0.28 & & & \\
\hline 34 & 0.15 & -0.16 & & & \\
\hline 45 & -0.10 & -0.08 & & & \\
\hline Eigenvalue & 10.13 & 7.54 & & 10.24 & 2.93 \\
\hline Discriminating Information (\%) & 41 & 31 & & 54 & 15 \\
\hline
\end{tabular}

\section{Track collection and identification}

The Cerrado region of Brazil is covered by a mosaic of forests, savannas and grasslands (EITEN 1993). Almost all nonvolant small mammal species usually caught by conventional trapping in the central part of Cerrado region belong to three families: Didelphidae, Echimyidae and Muridae, yelding a set of 45 trappable species (Tab. II, ALHO 1993). Our reference track collection included 22 of the 36 species found in forests and 16 of the 28 species found in savannas and grasslands of this region (Tab. II, AlHo 1993). Although that our reference track collection does not include all small mammal species found in the region, we regard it as a representative collection for the region, as the most common species of each habitat are represented in the collection. Most of the missing species were either rare, or trap-shy.

The use of multivariate analysis allowed the discrimination even of congeneric species, despite the small number of individuals sampled for some species (Fig. 5). The success in discriminating species was lower when many species were found in a given size class, as was the case of rodents weighting 30 to $60 \mathrm{~g}$ (Fig. 4). In practice, this forced us to use a two-step analysis: one exploratory analysis to eliminate clearly dissimilar species, and another analysis to classify field tracks among a selected subset of species.

Posterior footprints were better than anterior ones in distinguishing rodent and marsupial species (Figs 3 and 4). This was evident when we compared cursorial and arboreal species of both taxa. Soles of hindfeet of terrestrial rodents were clearly more elongated and narrow when compared with those of arboreal ones (see discriminant functions in table IV and the respective variables in figure 2). Among marsupials, hindfeet of arboreal and scansorial species had a clearly opposable finger, a trait also found in other arboreal groups like primates, chameleons and many perching and climbing birds (EMmons \& FEeR

Revista Brasileira de Zoologia 24 (2): 333-343, junho 2007 
1997, Feduccia 1999, Zug et al. 2001). At least among marsupials, arboreal locomotion performance shows a stronger correlation with posterior leg measures, than with anterior ones (Delciellos \& Vieira 2002).

There are two limitations in the use of tunnels: lack of individualization and dependence on a good local reference collection. The need for building a good reference collection for the region to be studied is the main limitation of tunnels as an inventory method. This is particularly limiting in inventories in less sampled regions. A good reference collection means a representative collection of the communities sampled (including rare species), based on good identifications of living animals, with multiple high quality footprints for each species. Since footprints records can be stored and analyzed latter, the reference collection can be built (or complemented) during and even after the inventory itself.

Lack of individualization means that it is not possible to differentiate individuals by their footprints, except when animals were toe-clipped (Justice 1961, Sheppe 1965). Hence, parameters that depend on individualization (density, home range area, survival, etc) cannot be estimated from tunnels only, but require the associated use of traps and toe-clipping. We believe that the clever and associated use of tunnels, traps and toeclipping may be more efficient (data points/sampling effort) than only trapping, without a significant loss of data quality. The tunnels can be particularly useful in studies that use pres- ence/absence data (inventories) or activity indexes (habitat/ microhabitat selection) (Ryan et al. 1993, Drennan et al. 1998). Tunnels as inventory method

Our results showed that the inventory method using tunnels was more efficient (data points/sampling effort) than trapping (Tab. V). A similar result was found by KING \& EDGAR (1977), who obtained higher efficiency for non-baited track recording (1.6\%), than for conventional trapping $(0.5 \%)$. The tunnels also provided a relevant description of the small mammal community of gallery forest by identifying rodents and marsupials of different habits: terrestrial, scansorial, arboreal, and semifossorial (Tab. II).

Using the same sampling effort, we obtained more information using tunnels than by using traps and all species sampled presented better or similar reaction to the tunnels in comparison with traps. Monodelphis spp. and Oryzomys megacephalus were better represented in tunnels than in traps (Tab. V). Other studies showed the same pattern, indicating that some small mammal species were reluctant to enter into traps (Sealander et al. 1958, Boonstra et al. 1992). Monodelphis spp. are clear examples of trap-shy species, that could be better studied by alternative sampling methods (Voss \& EMmons 1996).

When using tunnels, it is possible to find a track that does not fit any species in the reference collection. This happened to us with Oxymycterus-like footprints made in a gallery forest. If a good reference collection was already built, finding

Table V. Number of track records in ink-tracking tunnels and captures in Sherman traps during two inventories at Taquara Gallery forest in the Brazilian Cerrado. (A) There are four species of Monodelphis in study area (M. americana, M. domestica, M. kunzi e M. rubida), but only two are represented in our track collection thus precluding identification at species level, (B) we could not differentiate some anterior footprints of young Didelphis albiventris from those of adult Philander opossum, (C) rainfall during August 2000 inventory blurred some footprints precluding identification.

\begin{tabular}{|c|c|c|c|c|}
\hline & \multirow{2}{*}{ Species } & \multicolumn{2}{|c|}{ Track records inventory } & \multirow{2}{*}{ Captures 2001 inventory } \\
\hline & & 2000 & 2001 & \\
\hline \multicolumn{5}{|c|}{ Marsupiais } \\
\hline & Gracilinanus agilis & 28 & 100 & 52 \\
\hline & Monodelphis spp. ${ }^{\text {A }}$ & 3 & 8 & 0 \\
\hline & Didelphis albiventris & 0 & 7 & 2 \\
\hline & Didelphis or Philander ${ }^{\mathrm{B}}$ & 3 & 5 & - \\
\hline & Not identified & 7 & 0 & 0 \\
\hline \multicolumn{5}{|c|}{ Rodents } \\
\hline & Oecomys bicolor & 3 & 7 & 1 \\
\hline & Oecomys concolor & 0 & 2 & 1 \\
\hline & Rhipidomys macrurus & 0 & 10 & 9 \\
\hline & Oryzomys megacephalus & 2 & 1 & 0 \\
\hline & Proechimys longicaudatus & 6 & 2 & 3 \\
\hline & Oxymycterus delator & 1 & 0 & 0 \\
\hline & Not identified & 3 & 7 & 0 \\
\hline & Blurred footprints ${ }^{C}$ & 9 & 0 & - \\
\hline Total & & 65 & 149 & 68 \\
\hline
\end{tabular}


tracks of species not represented into it suggests either a rare species, or a species previously unknown in the region.

\section{CONCLUSIONS}

In this study, we showed that it was possible: 1 ) to sample small mammals in different conditions (distinct habitats, vegetation strata, and species with different locomotion behaviour) using tunnels; 2) to identify small mammal footprints using multivariate analysis, even if congeneric species are syntopic; and 3) to use tunnels as an efficient inventory method. The tunnels can be used in studies that need presence/absence data or an activity index: inventories, distribution, dispersion, daily activity, and habitat/microhabitat selection, besides ecomorphological studies. If individuals are marked by toe-clipping it is possible to study home range and social behavior (Justice 1961, Sheppe 1965, Brown 1969, Marten 1972, Lieberman 1973, KING \& EDGAR 1977). Morphometrical analyses using footprints could be performed to access intraspecific variations (age, sex and geographic variations). The simplicity, low cost, moderate field-effort and permanent record allow the use of tunnels as a suitable method that could complement trapping in ecological studies.

\section{ACKNOWLEDGEMENTS}

We thank Rosângela R.C. Nascimento for suggestions about inks and papers; Ricardo Bomfim for aid in the digitalization phase; Maria N.A. Menezes, Rafael N. Leite and André Faria for their aid in the fieldwork; Denis Briani and Marcelo L. Reis for providing additional tracks for reference collection; Cléber J.R. Alho, Emerson M. Vieira, Raul. A. Laumann, César A. Cuba-Cuba, and William Quatman for reviewing earlier drafts of the manuscript; and Johannes Erasmus for reviewing the english. Diego A. de Moraes, Marcus V. Vieira and Eduardo Leonardecz Neto provided helpful insights to the final version of manuscript. A.R.T. Palma received a scholarship from Coordenação de Aperfeiçoamento de Pessoal de Nível Superior (CAPES) and financial support from WWF-Brasil. R. GurgelGoncalves received a scholarship from Conselho Nacional de Desenvolvimento Científico e Tecnológico (CNPq).

\section{REFERENCES}

AlHo, C.J.R. 1993. Distribuição da fauna num gradiente de recursos em mosaico, p. 213-262. In: M. N. PinTo (Ed). Cerrado: caracterização, ocupação e perspectivas. Brasília, Editora Universidade de Brasília, 657p.

Apeldoorn, R.; M.El Daem; K. Hawley; M. Kozakiewicz; G. Merriam; W. Nieuwenhuizen \& J. Wegner. 1993. Footprints of small mammals. A field method of sampling data for different species. Mammalia 57: 407-419.

BeCKer, M. \& J.C. Dalponte. 1999. Rastros de mamíferos silvestres brasileiros. Brasília, Editora Universidade de Brasília, $180 \mathrm{p}$.
Boonstra, R.; M. Kanter \& C.J. Krebs. 1992. A tracking technique to locate small mammals at low densities. Journal of Mammalogy 73: 683-685.

BRown, L.E. 1969. Field experiments on the movements of Apodemus sylvaticus L. using trapping and tracking techniques. Oecologia 2: 198-222.

Carey, A.B. \& J. Witt. 1991. Track counts as indices to abundances of arboreal rodents. Journal of Mammalogy 72: 192-194.

Delciellos, A.C. \& M.V. Vieira. 2002. Ecomorphologial models for arboreal vertebrates: the case of the marsupial Philander frenata. HOLOS Environment 2: 195-207.

Drennan, J.E.; P. Beier \& N.L. Dodd. 1998. Use of track stations to index abundance of sciurids. Journal of Mammalogy 79: 352-359.

EMmons, L.H. \& F. Feer. 1997. Neotropical rainforest mammals: a field guide. Chicago, The University of Chicago Press, $2^{\text {nd }}$ ed., 307p.

EIten, G. 1993. Vegetação do Cerrado, p. 17-73. In: M. N. Pinto (Ed). Cerrado: caracterização, ocupação e perspectivas. Editora Universidade de Brasília, Brasília, 657p.

Feduccia, A. 1999. The origin and evolution of birds. New Haven, Yale University Press, $2^{\text {nd }}$ ed., 466p.

Fonseca, G.A.B.; G. Herrmann; Y.L.R. Leite; R.A. Mittermeier; A.B. Rylands \& J.L. PatTon. 1996. Lista anotada dos mamíferos do Brasil. Occasional Papers in Conservation Biology 4: 1-38.

JoHNs, A.D. 1979. A comparative assessment of methods of individual tracking within a population of Microtus agrestis (Mammalia, Muridae). Journal of Zoology 189: 333-338.

JusticE, K.E. 1961. A new method of measuring home ranges of small mammals. Journal of Mammalogy 42: 462-470.

King, C.M. \& R.L. Edgar. 1977. Techniques for trapping and tracking stoats (Mustela erminea); a review and a new system. New Zealand Journal of Zoology 4: 193-212.

LenZI, L.H.; M.A. Jansen \& P.M. Deane. 1984. The recent discovery of what might be a primordial escape mechanism for Trypanosoma cruzi. Memórias do Instituto Oswaldo Cruz 79: 13-18.

Lieberman, G.A. 1973. Desing of a tracking and observation station of small mammals studies. Canadian Field Naturalist 87: 455-456.

Lord, R.D.; A.M. Vilches; J.I. MaiszTegui \& C.A. Soldini. 1970. The track board, a relative census technique for studying rodents. Journal of Mammalogy 51: 828-829.

Marten, G.G. 1972. Censuring mouse populations by means of tracking. Ecology 53: 859-867.

MAYER, W.V. 1957. A method of determining the activity of burrowing mammals. Journal of Mammology 38: 531.

Mills, J.N.; T.L. Yates; J.E. Childs; R.R. Parmenter; T.G. Ksalek; P.R. Rollin \& C.J. Peters. 1995. Guidelines for working with rodents potentially infected with hantavirus. Journal of Mammalogy 76: 716-722.

Nitikman, L.Z. \& M.A. Mares. 1987. Ecology of small mammals in a gallery forest of central Brazil. Annals of the Carnegie Museum 56: 75-95. 
Ratter, J.A. 1980. Notas sobre a vegetação da Fazenda Água Limpa (Brasília - DF). Brasília, Editora Universidade de Brasília, 136p.

Ratz, H. 1997. Identification of footprints of some small mammals. Mammalia 61: 431-441.

ReID, F.A. 1997. A field guide to the mammals of Central America and Southeast Mexico. Oxford, Oxford University Press, 334p.

Ryan, J.M.; G.K. Creighton \& L.H. Emmons. 1993. Activity patterns of two species of Nesomys (Muridae: Nesomyinae) in a Madagascar rain forest. Journal of Tropical Ecology 9: 101-107.

Sealander, J.A.; D.N. Griffin; J.J. de Costa \& D.B. Jester. 1958. A technique for studying behavioral responses of small mammals to traps. Ecology 39: 541-542.

SHEPPE, W. 1965. Characteristics and uses of Peromyscus tracking data. Ecology 46: 630-634.

Silva Júnior, M. C.; J.M. Felfili; P.E. Nogueira \& A.V. Rezende. 1998. Análise florística das matas de galeria no Distrito Federal, p. 51-84. In: J.F. Ribeiro (Ed). Cerrado: matas de gale- ria. Planaltina, Embrapa, 164p.

Smallwood, K.S. \& E.L. Fitzhugh. 1993. A rigorous technique for identifying individual mountain lions Felis concolor by their tracks. Biological Conservation 65: 51-59.

Strauss, R.E. \& F.L. Bookstein. 1982. The truss: body form reconstructions in morphometrics. Systematic Zoology 31: 113-135.

TAYLOR, C.A. \& M.G. RAPHAEL. 1988. Identification of mammal tracks from sooted track stations in the pacific north west. California Fish and Game 74: 4-15.

Voss, R.S. \& L.H. EMmONs. 1996. Mammalian diversity in neotropical lowland rainforests: a preliminary assesment. Bulletin of American Museum of Natural History 230: 1-115.

Weksler, M.; A.R. Percequillo \& R.S. Voss. 2006. Ten new genera of Oryzomine rodents (Cricetidae: Sigmodontine). American Museum Novitates 3537: 1-29.

Zug, G.R.; L.J. VitT \& J.P. CAldwell. 2001. Herpetology: an introductory biology of amphibians and reptiles. San Diego, Academic Press, $2^{\text {nd }} e d ., 630 p$.

Received in 15.VIII.2006; accepted in 30.IV.2007. 